\title{
Masking Level Difference (MLD): Literature Review
}

\author{
Patricia da Silva de Paula ${ }^{1}$, Silvana Maria Monte Coelho Frota ${ }^{2}$ and Lilian Felipe ${ }^{3}$ \\ ${ }^{1}$ Master in Speech Therapy by Veiga de Almeida University, Speech-Language Pathologist by Fluminense Federal University, South America \\ ${ }^{2}$ PhD in Human Communication Disorders by Sao Paulo Federal University. Professor at Rio de Janeiro Federal University, South America \\ ${ }^{3}$ Post Doc Maastricht University - The Netherlands. PhD in Health Sciences Minas Gerais Federal University. Coordinator and Chair Professor at \\ Fluminense Federal Univesity, South America
}

Submission: February 20, 2017; Published: March 10, 2017

*Corresponding author: Patricia da Silva de Paula, Master in Speech Therapy by Veiga de Almeida University, Speech-Language Pathologist by Fluminense Federal University, South America

\begin{abstract}
Masking Level Difference composes a tests set for the central auditory processing behavioral evaluation and estimates decoding binaural interaction abilities. MLD test consist of auditory level measurement by emitting a pulsatile clear tone to both ears, at the same moment as a masker rustle is being emitted. This work has the objective of reviewing literature over MLD, providing general information concerning to the test. Binaural Interaction Tests evaluate central auditory nervous system (CANS) on processing dissimilar information, but complementary, emitted to both ears. The rustle has the objective of masking the auditory signal, in a permanent stage. On that test, the individual is submitted simultaneously to an auditory signal and to a rustle. However, emitting a rustle to the other ear becomes the auditory sign more audible.

MLD is a psychological/auditorial phenomenon, in which detection or recognizing a binaural or monoaural sign emitted, is improved adjoining a competitive binaural rustle. An individual is normally evaluated at the same stage (speaking, pulsatile tone, masker rustle in both ears) and in a different stage (one of the signs is emitted to $180^{\circ} \mathrm{C}\left[356^{\circ} \mathrm{F}\right]$ in a diverse way from the initial one, just to one ear, while the other one is kept in a reverse stage). The test allows identifying individuals with compromised low brainstem.
\end{abstract}

Keywords: Masking Level Difference; MDL; Masking Auditory Processing

\section{Introduction}

Hearing is a fundamental meaning to life, because it is the basis of human communication allowing the insertion of the individual in society. The auditory system allows the processing of acoustic events whose function is to select speech sounds over competitive factors such as noise [1-10]. The auditory processing refers to the efficiency and effectiveness with which the central nervous system (CNS) uses auditory information. It is the basis for complex actions such as understanding spoken language, not being a closed process, interacting intimately with other neural systems and being influenced by experience, environment and active training; its alteration affects negatively the quality of life of many people [11].

Among the central auditory functions that comprise auditory processing, we find temporal processing and binaural interaction. It is highlighted that temporal auditory processing is especially important in speech perception, discrimination of subtle clues, recognition of phonemes and their distinctive features and discrimination of similar words. On the other side, binaural interaction is described as a process that allows the integration or separation of stimulus related to interhemispheric cooperation. The binaural interaction is evaluated through two main behavioral procedures: the Binaural Fusion and Masking Level Difference (MLD) tests [12-21].

Because it is part of the evaluation of binaural interaction, the Masking Level Difference (MLD) deserves to be highlighted because of its importance, justifying this literature review. In performing the MLD, peculiarities concerning the performance of the test must be well known in order to avoid mistakes in the interpretation of the result. The main objective of this review was to describe the central aspects regarding the achievement, interpretation and clinical utility of MLD [22-26].

\section{Method}

This review was carried out through the search of the subject descriptors «Masking Level Difference», «MLD», «Masking» and «Auditory Processing», «Temporal Processing» in the Virtual 
Health Library (BVS) databases, including articles in English and Portuguese languages, published from 1982 to 2010. From this primary selection, scientific papers and medical books were selected and added.

\section{Literature Review}

\section{Central Auditory Processing}

Speech perception involves the experiences of the individual during his life and the importance he or she attributes to the auditory stimulus; these aspects involved in this process are not dependent only on the peripheral and central auditory system. Auditory processing involves, besides the auditory discrimination, the abilities of localization and lateralization of the sound, recognition, temporal aspects, tests of dichotic listening and with degraded acoustic signals. Auditory discrimination involves the perception of acoustic stimulus in very fast sequences requiring accuracy of the information that is brought to the brain, consequently enabling the decoding and understanding of speech mainly in unfavorable situations, such as with the presence of background noise and competitive speech [27-34]. In short, the auditory processing is the effective use of auditory information, that is, what the human being does with what he or she hears [35].

\section{Temporary Auditory Processing}

Temporal auditory processing can be defined as the perception of sound or sound alteration within a defined and restricted period, that is, it refers to the ability to perceive or differentiate stimulus that are presented in rapid succession, becoming a fundamental component for greater auditory processing capacity [36-40]. Much evidence suggests that temporal processing skills are the basis of auditory processing, specifically regarding to speech perception. The argument that supports this proposition is that many characteristics of auditory information are, in some way, influenced by time [41-46].

Therefore, the temporal processing can be defined as the perception of the sound or its change within a time domain. It can be observed in many levels from the most basic (regulation of neural time in the auditory nerve) to the most complex (cortical processing of binaural hearing and speech perception). Therefore, it allows the human being to perceive the sounds of the speech and comprehension of oral language [46-54].

\section{Binaural Interaction}

Among the behavioral tests that evaluate auditory processing there is the binaural interaction test that evaluates the ability of the central auditory nervous system to process different but complementary information presented to both ears [55-60]. Auditory complaints concerning difficulties in locating the direction of the sound source, perceiving speech in noisy environments, or perceiving speech in environments where there are many people speaking at the same time may be associated with impairment of normal binaural integration functions [61-65]. In summary, binaural interaction is the ability to perceive and organize the sounds of the environment, which depends heavily on the simultaneous use of the two ears, on the neural interaction that occurs with the signals received by the two ears, and on how the hearing information is processed [6567]. The evaluation of binaural interaction consists of two main behavioral procedures: the Binaural Fusion test and the Masking Level Difference (MLD) test.

\section{Masking Level Difference (MLD)}

First described by Hirsh [68-78], MLD can use a pure a tone stimulus or a speech one. The Masking Level Difference is a psychoacoustic phenomenon in which the detection or recognition of a monaural or binaural signal presented is improved in the presence of a competitive binaural noise. This improvement results from the use of the auditory system of a subtle binaural event and differences in amplitude levels between simultaneously presented signals or masked signals. The MLD represents an advantage in the detection or recognition of the altered binaural phase in reference to the unchanged condition phase. Normal CANS listeners demonstrate masking suppression under MLD conditions, while listeners with auditory system alterations do not demonstrate comparable masking suppression. Even though MLD is a central process of interaction of the two ears (sub thalamic), it can be affected by the peripheral auditory system [78-86].

Masking Level Difference (MLD) refers to the detection of a breakpoint to the signal that can occur in two masking conditions - S0N0, homophase and S $\pi \mathrm{N} 0$, antiphase - both signal and masking; they are binaural in phase and out of phase. The test consists of 10 homophasic stimulus, 12 anti-phasic stimulus and 11 no-tone stimulus. It starts from the most favorable signalnoise ratio to the least favorable in the three conditions (SONO, S $\pi$ N0 e NT) The subject hears a chirp for a few seconds; during this chirping, sometimes he or she hears a tone and sometimes not. At each presentation, he or she tells the examiner whether there is the tone or not. The breakpoint difference at which the signal is last perceived under the conditions SONO and SINN determines the MLD result [87-89].

Musiek et al. [89-92] gave a brief introduction on how to perform the MLD test. The authors did the test using a pure tone at $500 \mathrm{~Hz}$, presented in both ears along with a continuous broadband noise presented at $60 \mathrm{dBHL}$. Musiek et al. [93] named both as homophase and antiphase conditions. They reinforced both the importance of symmetric and normal breakpoint for MLD research, as well as the variables that may interfere in the study as type of signal used (pure tone, spondaneous words); the type and level of sound pressure of the noise used and the condition of phase change of one of the stimulus. They reported that values lower than $6 \mathrm{~dB}$ are not considered normal for adults and that this test is sensitive for brainstem lesions. 
Wilson et al. [94] performed a series of experiments in order to develop a protocol for MLD $(500 \mathrm{~Hz})$ of simple application that could be used in clinical practice. The authors observed that $95 \%$ of the listeners presented MLD greater than or equal to $10 \mathrm{~dB}$, this being the reference value of normality for the test. The version of the MLD that uses pure tones with the help of the audiometer consists of the presentation of a pulsatile tone, usually at $500 \mathrm{~Hz}$ in both ears, at the same time as a narrow band masking noise presented binaurally at $40 \mathrm{dBNA}$. The differential frequency breakpoint of the $500 \mathrm{~Hz}$ frequency is determined using steps of $1 \mathrm{~dB}$ between three different test conditions: Noise and pure tone presented in the same phase, reversed phase noise in one ear and pure tone in the two ears, pure tone in inverted phase in one of the ears and phase noise in both ears. The patient is advised to warn when they no longer hear the stimulus presented. The first errors of both conditions are subtracted; the result is obtained in decibels $(\mathrm{dB})$.

MLD can also be performed using the CD produced by Richard Wilson and marketed by Auditec St. Louis. Novak and Anderson [27] observed that elderly patients with «neural presbycusis» had significant reductions in MLD size. Wilson et al. [94] studied MLD comparing two different types of noise: filtered white noise and modulated amplitude noise, and they described that these two different types of noise showed different MLD values for differing in their masking effectiveness. The authors reinforced the idea that a clinician using the MLD method in the search for central changes should develop their own normality criteria. Kramer et al. $[95,96]$ reported that stutterers had lower MLDs than non-stutterers did. This result was interpreted as follows: stutterers have worse auditory processing abilities than nonstutters and probably have greater difficulty with temporal processing.

Hall and Grose [30], in a longitudinal study, demonstrated that MLD in children younger than 5/6 years old was lower than MLD in adults. The study concluded that reduced MLD did not appear to be a result of peripheral factor, but was attributed to developmental differences probably related to central auditory processing. Since MLD is one of the binaural interaction tests that are designed to evaluate the ability of the Central Auditory Nervous System (CANS), to receive information in both ears and to unify them in a perceptual event; it is believed that this unification occurs in the brainstem. As a consequence, it is assumed that this test is sensitive for pathologies of the brainstem and may have results affected by brain lesions; corroborating that listeners who present alterations of the auditory system do not demonstrate release of masking, suggesting probable impairment of brainstem [45-50].

There are no Brazilian studies that present normality values for MLD, and the values of international surveys are accepted as references in clinical practice. This bibliographic study evidences the importance of continuity in the study of binaural interaction abilities, including the Masking Level Difference
(MLD) test, which demonstrates to be closely linked with the ability to locate the sound source and speech recognition in the presence of noise.

\section{References}

1. Abrams D A, Kraus N (2008) Auditory pathway representations of speech sounds in humans. Trends in Neurosciences. USA 28(4): 611626.

2. Allum-Mecklenburg D, Babighian G (1996) Cochlear performance as an indicator of auditory plasticity in humans. In: Salvi RJ et al. (Eds). Auditory System Plasticity and Regeneration. Thieme, New York, USA, pp: 395-404.

3. ASHA American Speech-Language-Hearing Association (1996) Central Auditory Processing: current status and implications for clinical practice. Am J Audiol 5(2): 41-54.

4. ASHA-American Speech-Language-Hearing Association (2006) Central Auditory Processing: current status and implications for clinical practice. Am J Audiol 3(1): 30-37.

5. Bailey P J, Snowling M J (2002) Auditory processing and the development of language and literacy. Br Med Bull 63: 135-146.

6. Bamiou D (2007) Measures of binaural interaction. In FE Musiek, GD Chermack. Handbook of (central) auditory processing disorder: Auditory Neuroscience and diagnosis San Diego: Plural Publishing pp: 257-286.

7. Baran Ja (1993) Neuroradiology. Case studies. Singular Publishing Group, San Diego, USA.

8. Baranja, Musiek FE (1991) Behavioral assessment of the central auditory nervous system. In W. F. Rintelmann (Ed.), Hearing assessment ( $\left.2^{\text {nd }} e d\right), p p: 549-602$.

9. BELLIS TJ (1996) Central Auditory Processing Disorders. From Science to Practice. Singular Publishing Group San Diego USA.

10. (2003) Assessment and management of central auditory processing disorders in the educational setting from science to practice. ( $2^{\text {nd }} e d n$.), Thomson Delmar Learning, New York. USA, 488p.

11. Kraus N, BANAI K (2007) Auditory- Processing malleability: focus on language and music. Current Directions in Psychological science 16(2): 105-110.

12. Bess FH, Hedley-Williams A, Lichtenstein MJ (2001) Avaliação audiológica dos idosos. In: Musiek FE, Rintelmann, WF (eds). Perspectivas atuais em avaliação auditiva. Sao Paulo: Manole chap 12: 343-369.

13. (1996) Assessment and management of central auditory processing disorders: from science to practice. San Diego Singular Publishing Group, USA.

14. Bocca E et al. (1954) Apud Rintelmann WF, Lynn GE. Speech stimuli for assessment of central auditory disorders. In: Konkle DF, Rintelmann WF, editors. Principles of Speech Audiometry. University Park Press, Baltimore, USA, 231-283.

15. BOOTHROYD A (1986) The sense of hearing. - In: Speech, Acoustic and Perception Disorders. The Pro-ED Studies in Communicative Disorders, Austin, USA.

16. BONALDILV, ANGELIS M A, SMITH R L (1997) Hodologia do Sistema Auditivo: Vias auditivas. In: PEREIRA LD, SCHOCHAT E (edit.) - In: Processamento Auditivo Central- Manual de Avaliação. Sao Paulo, Publisher Lovise p: 19-25.

17. BUONOMANO DV (2002) e Karmarkar, U.R. How do we tell time? Neuroscientist 8(1): 42-51. 
18. CIASCA SM (2003) Distúrbios de Aprendizagem: Proposta de Avaliação Interdisciplinar. Sao Paulo: Casa do Psicólogo.

19. DESGUALDO LP (2004) Avaliação comportamental do processamento auditivo em indivíduos gagos. Pró-Fono R. Atual. Scient. $\left(20^{\text {th }}\right.$ edn). n.1 Barueri.

20. DLOUHA O, NOVAK A, VOKRAL J (2007) Central auditory processing disorder (CAPD) in children with specific language impairment (SLI) Int J Pediatric Otorhinolaryngology 71(6): 903-907.

21. FELIPPE ACN, Colafêmina, JF, COSTA JÚNIOR ML (2001) Análise comparativa entre os resultados do teste de escuta dicótica consoantevogal e o desempenho em tarefas de leitura-escrita. Pró-fono 13(1): 23-29.

22. Ferre JM (1997) Processing Power. A Guide to CAPD Assessment and Management. Communication Skill Builders, San Antonio, USA.

23. Fitch RH, Miller S, Tallal P (1997) Neurobiology of speech perception. Ann Ver Neurosci. 20: 331-353.

24. Frota S, Avaliação Básica da Audição (2003) In: (Org). Fundamentos em fonoaudiologia: audiologia. ( $2^{\text {nd }}$ edn). Rio de Janeiro: Guanabara Koogan 41-59.

25. Sampaio F Logoaudiometria (2003) In: Frota S (Org). Fundamentos em fonoaudiologia: audiologia. ( $2^{\text {nd }}$ edn). Rio de Janeiro: Guanabara Koogan p.61-69.

26. Logoaudiometria (2006) In: Frota S (Org). Fundamentos em fonoaudiologia: audiologia. $\left(1^{\text {st }}\right.$ edn). (revised) Rio de Janeiro: Guanabara Koogan 40-47.

27. GELFAND SA (1984) The contralateral acoustic reflex threshold. In: Silman S. The acoustic reflex: basic principles and clinical applications. Academic Press, Orlando, Florida, USA.

28. Goldstein DPE, Stephens SDG (1975) Masking Level Difference: a measure of auditory processing capability. Audiology 14: 354-367.

29. GLORIG A, NIXON J (1960) Distributions of hearing loss in various populations. Ann Otol Rhinol Laryngol 69: 497-516.

30. Grose John H, Poth Elizabeth A (1994) Masking Level Differences for Tones and Speech in Elderly Listeners with Relatively Normal Audiograms. Journal of Speech and Hearing Research 37: 422-428.

31. Hall JW, Grose JH (1990) The masking-level difference in children. J Am Acad Audiologic 1:81-88.

32. COKELY JA, GROSE JH (1988) Combined monoaural and binaural masking release. J Acoust Soc Am 83(5): 1839-1845.

33. HAGE SRV, FAIAD LNV (2005) Perfil de Pacientes com Alteração de Linguagem Atendidos na Clinica de Diagnóstico dos Distúrbios da Comunicação. CEFAC. Magazine. Bauru: Sao Paulo University.

34. HIRSH IJ (1948) The influence of inter aural phase on inter aural summation and inhibition. Journal of the Acoustical Society of America 20(4): 536-544.

35. Webster FA (1949) Some determinants of inter aural phase effects. acoust Soc Amer 21: 496-501.

36. Jerger J (1970) Clinical experience with impedance audiometry. Arch Otoloryng 92(4): 311-324.

37. Specks CE, Trammell JA (1968) New approach to speech audiometry. Speech Hear Disord 33(4): 318-328.

38. Jerger S, Jerger J (1989) Alterações auditivas: um manual para avaliação clínica. Atheneu: Sao Paulo, South America.

39. Jerger J, Brown D, Smith S (1984) Effect of peripheral hearing loss on the masking level difference. Arch Otolaryngol 110(5): 290-296.
40. Jeffress LA, Blodgett HC, Sandel TT, Wood III CL (1963) Masking of tonal signals. J Acoust Soc Am 28: 416-426.

41. Yost WA (1965) Tone on Tone masking for three binaural listening conditions. J Acoust Soc Am 52(4B): 1234-1237.

42. Johnson KL (2008) Brain stem encoding of voiced consonant-vowel stop syllables. International Federation of Clinical Neurophysiology, USA, 119: 2623-35.

43. Junqueira CAO, Frizzo ACF (2002) Potenciais evocados auditivos de curta, média e longa latência. In: Aquino AMCM (Org). Processamento auditivo: eletrofisiologia \& psicoacústica. Publisher Lovise, Sao Paulo, USA.

44. Katz Jack (1999) Tratado de Audiologia Clínica. (4 $4^{\text {th }}$ edn). Manole, Sao Paulo, USA.

45. Kelly BR, Davis D, Hedge MN (1994) Assessing auditory problems. In: Clinical Methods and Practicum in Audiology. Singular Publishing Group, California, USA, 179-211.

46. Kramer MB, Green DE, Guitar BA (1987) comparison of stutterers and non-stutterers on masking level difference and synthetic sentence identification tasks. J Commun Disord 20(5): 379-390.

47. Nicol T (1994) Brainstem origins for cortical "what" and "where" pathways in the auditory system. Trends in Neurosciences, USA, 28(4): 176-80.

48. Mcgee TGC, Littman T, Nicol T (1994) Discrimination of speech-like contrasts in the auditory thalamus and cortex. J Acoust Soc Am 96(5): 2758-2768.

49. Lasky EZ, Kartz J (1983) Perspectives on central auditory processing, In: Lasky EZ, Kartz J (Eds). Central auditory processing disorders problems of speech, language and learning. Texas: pro-ed, 3-9.

50. Lynn GE, Gilroy J, Taylor PC, Leiser RP (1981) Binaural masking-level differences in neurological disorders. Archives of Otolaryngology 107(6): 357-362.

51. Loureiro MHA (2006) Limiar de reconhecimento de fala na língua portuguesa: um estudo com palavras trissilábicas. Acta ORL 24(4): 225-231.

52. Machado SF (2003) Processamento Auditivo: Uma nova abordagem. Publisher Plexus, Sao Paulo, USA, 140.

53. Momensohn-Santos TM, Brunetto-Borgianni LM, Brasil LA (2007) Caracterização audiológica das principais alterações que acometem o sistema auditivo. In: Momenshon-Santos TME, Russo ICP (Org). Prática da audiologia clínica. (6 ${ }^{\text {th }}$ edn). Cortez, Sao Paulo, USA, 311-360.

54. Musiek FE (1994) Frequency (pitch) and duration pattern tests. J Am Acad Audiol, ( $5^{\text {th }}$ edn). 265-268.

55. Baran JA, Pinheiro ML (1993) Duration pattern recognition in normal subjects and patient with cerebral and cochlear lesions. Audiology 29: 304-313.

56. Musiek FE (1994) Frequency (pitch) and duration pattern tests. J Am Acad Audiol 5(4): 265-268.

57. Musiek FE, Bellis TJ, Chermak GD (2005) Non-modularity of the central auditory nervous system: Implications for (central) auditory processing disorder. Am J Audiol 14(2): 128-138.

58. Geurkink NA (1980) Auditory perceptual problems in children: considerations for the otolaryngologist and audiologist. Laryngoscope 90(9 Pt 1): 962-971.

59. Murphy CFB, Schochat E (2007) Influência de paradigmas temporais em testes de processamento temporal auditivo. Pró-fono 19(3): 259266. 


\section{Global Journal of Otolaryngology}

60. Noffsinger D, Olsen WO, Carhart R, Hart CWE, Sahgal V (1972) Auditory and vestibular aberration in multiple sclerosis. Acta OtoLaryngological 303: 1-63.

61. D Kudziel, SE Applebaum (1975) Value of special auditory testes in the latero-medial inferior pontine syndrome. Ann Otorhinol larynngol 84(3 Pt 1): 384-390.

62. Norrelgen F, Lacerda FE, Forssberg H (2001) Temporal resolution of auditory perception in relation to perception, memory and language skills in typical children. J Learn Disabil 34(4): 359-369.

63. Novak REE, Anderson CV (1982) Differentiation of types of presbycusis using masking-level difference. J Speech Hear Res 25(4): 504-508.

64. Olsen WO, Noffsinger D, Carhart R (1976) Masking level differences encountered in clinical populations. Audiology 15(4): 287-301.

65. Pen Mangabeira-Albernaz, P Logoaudiometria (1997) In: Pereira LD, Schochat E, Processamento Auditivo Central. Publisher Lovise, Sao Paulo, USA, p.42.

66. Pereira LD (1996) Identificação de desordens do Processamento Auditivo Central através de observação comportamental: organização de procedimentos padronizados. In: Schochat E (Org.). Processamento Auditivo. Publisher Lovise, Sao Paulo, USA, p.43-56.

67. Cavadas M (2003) Processamento Auditivo Central. In: Frota S (Org.) Fundamentos em Fonoaudiologia: audiologia. $\left(2^{\text {nd }} e d n\right)$. Rio de Janeiro: Guanabara Koogan, pp. 135-160.

68. Perez-Abalo MC, Gaya JA, Savio G, Ponce DE Leon M, Perera M, Reigosa $\mathrm{V}$ (2009) Early detection and intervention of hearing impairment in Cuba: outcome after 20 years. Rev Neurol 41(9): 556-563.

69. Phillips SL, Gordon-Salant S, Fitzgibbons PJ, Yeni-Komshian G (2000) Frequency and temporal resolution in elderly listeners with good and poor word recognition. J Speech Lang Hear Res 43(1): 217-28.

70. Pinheiro, Maria Madalena Canina, Pereira, Liliane Desgualdo (2004) Processamento auditivo em idosos: estudo da interação por meio de testes com estímulos verbais e não-verbais. Rev Bras Otorrinolaringo (70 ${ }^{\text {th }}$ edn) $, 2: 209-214$.

71. Pinheiro ML, Musiek FE (1985) Sequencing and temporal ordering in the auditory system. In: Pinheiro ML, Musiek FE. Assessment of central auditory dysfunction foundations and clinical correlates. Williams \& Wilkins, Baltimore, Europe pp.219-238.

72. Poeppel D (2003) The analysis of speech in different temporal integration windows: cerebral lateralization as "asymmetric sampling in time". Speech Commun 41(1): 245-255.

73. Quaranta A, Cervellera G (1977) Masking level differences in central nervous system diseases. Arch Otolaryngol 103(8): 482-484.

74. Rabelo CM (2008) Avaliação eletrofisiológica e comportamental do processamento temporal. 2008. 159f. Tese (Doutorado em Ciências da Reabilitação) - Medicine College of Sao Paulo University, Sao Paulo, USA.

75. Reis ACMB, Lima AR, Silveira NL, Duarte SG (2002) Tomografia por emissão positrônica (PET): utilização na avaliação funcional da audição. In: Aquino AMCM (Org). Processamento auditivo: eletrofisiologia \& psicoacústica. Sao Paulo: Publisher Lovise, p. 87-99.

76. Robinson D, Jeffress L (1963) Effect of varying the inter aural noise correlation on the detectability of tonal signals. J Acoust Soc Am 35(12): 1947-1952.

77. Russo ICP, Lopes LQ Brunetto-Borgianni LM, Brasil LA (2007) Logoaudiometria. In: MOMENSHON-SANTOS, T.MeRUSSO, I.C.P. (ORG).
Prática da Audiologia Clínica. (6 ${ }^{\text {th }}$ edn). Publisher Cortez, Sao Paulo, USA, pp. 135-154.

78. IÊDA Chaves Pacheco, Santos Tereza Maria M (2007) Prática da Audiologia Clínica. Publisher Cortez, Sao Paulo, USA.

79. Samelli AG, Schochat E (2008) Processamento auditivo, resolução temporal e teste de detecção de gap: revisão de literatura. CEFAC Magazine, (10 $\left.{ }^{\text {th }} \mathrm{edn}\right), 3: 369-77$.

80. Santos MFC, Pereira LD (1996) Teste de escuta dicótica com dígitos. In: CONGRESSO PAULISTA DOS DISTÚRBIOS DA COMUNICACC̃̃O HUMANA, 1. São Paulo. Anais. Sao Paulo: [unnumbered], USA.

81. Escuta com dígitos. In: PEREIRA LD, Schochat (Eds), Processamento Auditivo Central: Manual de avaliação. $\left(1^{\text {st }}\right.$ edn). Publisher LOVISE, Sao Paulo, USA, pp. 147-149.

82. Santos MFC (1998) Processamento auditivo central: teste dicótico de dígitos em crianças e adultos normais. Tese (Mestrado em Fonoaudiologia) - Paulista Medicine School of Sao Paulo Federal University, Sao Paulo, USA.

83. Shinn JB (2003) Temporal processing the basics. Hear J 56 (7): 52.

84.(2007) Temporal processing and temporal patterning tests. In: MUSIEK, volume I. San Diego: Plural Publishing Cap 10: 231-256.

85. Stephens, Simon DG, Thornton, Arthur RD (1976) Subjective and electro physiologic tests in brain-stem lesions. Arch Otolaryngol 102(10): 608-613.

86. Schoeny Z, GE Carhart R (1971) Effects of unilateral Meniere's disease on masking-level differences. J Acoust Samer R 50(4): 11143-1150.

87. Schochat E (1998) Processamento Auditivo Central: Revisão da Literatura. Revista Brasileira de Otorrinolaringologia 5(1): 24-31.

88. Samelli AG, Schochat E (2008) The gaps-in-noise test: GAP detection thresholds in normal - hearing young adults. Int J Audiol 47(5): 238245 .

89. Sweetow RE, Reddell R (1978) The use of masking level differences in the identification of children with perceptual problems. J Am Audiol Soc 4(2): 52-56.

90. Waryas PA, Batten RR (1985) Masking level difference response norms from learning disabled individuals. Journal of Child Communication Disorders 8(2): 147-153.

91. Wilson Richard H, Arcos JG, Brown CJ, Benett LA (1984) Maskinglevel difference in filtered-random and amplitude-modulated-noise. J Speech Hear Res 27(2): 267-274.

92. Wilson RH, Moncrieff DW, Townsend EA, Pillion AL (2003) Development of a 500-Hz, Masking-Level Difference Protocol for Clinic Use. J Am Acad Audiol 14(1): 1-8.

93. Wilson RH, Strouse AL (2001) Audiometria com estímulos da fala. In Musiek FE, Rintelmann WF (eds). Perspectivas atuais em avaliação auditiva. Manole Cap, São Paulo, USA, 12: 21-30.

94. Wong PC, Parsons LM, Martinez M, Diehl RL (2004) The role of the insular cortex in pitch pattern perception: the effect of linguistic contexts. Journal Neurosci 24(41): 9153-9160.

95. Elena ZaidanI, Adriana Pontin Garcia, Maria Lucy Fraga Tedesco, Jane A Baran (2008) Desempenho de adultos jovens normais em dois testes de resolução temporal. Pró-fono 20(1): 19-24.

96. Masking Level Difference (MLD). 
(C) - This work is licensed under Creative (C) Commons Attribution 4.0 License BY DOI: $10.19080 /$ GJO.2017.05.555655
Your next submission with Juniper Publishers will reach you the below assets

- Quality Editorial service

- Swift Peer Review

- Reprints availability

- E-prints Service

- Manuscript Podcast for convenient understanding

- Global attainment for your research

- Manuscript accessibility in different formats

( Pdf, E-pub, Full Text, Audio)

- Unceasing customer service

Track the below URL for one-step submission https://juniperpublishers.com/online-submission.php 